\title{
A diverse and resilient financial system for investments in the energy transition Friedemann Polzin ${ }^{1}$, Mark Sanders ${ }^{1}$ and Florian Täube ${ }^{2,3}$
}

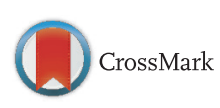

\begin{abstract}
Diversity makes the financial system more resilient. In addition, there is a diverse investment demand to make the transition to a more sustainable energy system. We need, among others, investment in energy transition, circular resource use, better water management and reducing air pollution. The two are linked. Making the financial system more diverse implies more equity, less debt, more non-bank intermediation and more specialized niche banks giving more relation-based credit. This will arguably also increase the flow of funds and resources to innovative, small-scale, or experimental firms that will drive the sustainability transition. Higher diversity and resilience in financial markets is thus complementary and perhaps even instrumental to engineer the transition to clean energy in the real economy.
\end{abstract}

\footnotetext{
Addresses

${ }^{1}$ Utrecht University School of Economics (USE) and Sustainable Finance Lab (SFL), Kriekenpitplein 21-22, 3584 EC Utrecht, The Netherlands

2European Management School (EMS), Rheinstraße 4N, 55166 Mainz, Germany

${ }^{3}$ Université libre de Bruxelles, SBS-EM, ICITE, Avenue F.D. Roosevelt 50 CP 114/04, B-1050 Brussels, Belgium

Corresponding author: Täube, Florian (f.taeube@ems.de, ftaube@ulb.ac. be)
}

\section{Current Opinion in Environmental Sustainability 2017, 28:24-32 \\ This review comes from a themed issue on Sustainability governance and transformation}

Edited by Carolien Kroeze, Harald Vranken, Marjolein Caniels and Dave Huitema

Received: 1 February 2017; Accepted: 10 July 2017

http://dx.doi.org/10.1016/j.cosust.2017.07.004

1877-3435/৫ 2017 Elsevier B.V. All rights reserved.

\section{Introduction}

A 'grand challenge' facing humanity in the 21st century, perhaps the biggest challenge humanity has ever faced, is to manage the energy transition to a more decentralized and renewable system $\left[1,2^{\bullet \bullet}, 3\right]$. Technologically and energetically this transition is feasible and even economical $\left[4,5^{\bullet}, 6,7^{\bullet}\right]$. Our modern economies have become completely dependent on a reliable and low-cost supply of heat, power and mobility, and fossil fuels still supply
$80 \%$ of that demand [8]. This has to drop to $0 \%$ by 2050 to stay below the $2^{\circ} \mathrm{C}$ increase in global temperature compared to pre-industrial levels [4]. Transforming our energy systems into more decentralized and renewable energy sources will require a vast deployment of innovations and, accordingly, huge investment $\left[5^{\circ}, 9\right]$. Estimates for the total investment begin at about USD 700 billion [10] which amounts to a mere $1 \%$ of global GDP [6]. However, this amount simply pales in comparison to the daily trade in global financial markets ${ }^{\mathrm{a}}$ or total estimated financial losses in the 2008 crisis. $^{\mathrm{b}}$

There is no doubt that the financial sector could, in principle, finance the transition $\left[11^{\bullet \bullet}\right]$. But all too often, this is taken for granted in the literature $\left[2^{\bullet \bullet}, 12,13\right]$ neglecting underlying issues. ${ }^{\mathrm{c}}$ The financial system gives direction to the development in the real economy. Its traditional role is to mobilize and transform savings into productive investments [14] and the latter crucially includes investments in new capacities of existing firms, new ventures, new technologies and complementary assets such as infrastructure across a range of institutional and geographical contexts [15] that the transition to sustainability will entail $\left[16,17,18^{\bullet}\right]$. The real economy

\footnotetext{
${ }^{a}$ Reuters reports foreign exchange trade on a daily basis is about 3-5 USDtn: http://www.reuters.com/article/global-forex-volumesidUSL5N1GK1F5. Adding global bond and stock markets and total bank credit would multiply that number manifold.

${ }^{\mathrm{b}}$ Global financial losses in the crisis have been estimated at staggering numbers of 10-15 USDtn: https://blogs.wsj.com/economics/2012/10/01/ total-global-losses-from-financial-crisis-15-trillion/.

${ }^{\mathrm{c}}$ Theoretically there are three underlying problem categories. First consider the $\mathrm{CO}_{2}$ abatement options that are in fact Net Present Value (NPV) positive under current circumstances [94]. With efficient financial markets, such opportunities should not exist, but they do, in fact [94-96]. Incentives and corporate governance structures of large, publicly traded companies focus typically on capital expenditure (CAPEX). Gains from clean energy investments typically come in the form of lower operational costs (OPEX) [48,97]. Any financial intermediary would be willing and able to finance these investments with debt. The collateral is high quality and OPEX reductions cover interest payments and installments. The short time horizon and high discount rates of most shareholders, however, make minimizing CAPEX more attractive than minimizing OPEX. In a second situation NPV is close to zero or contextspecific. Such specificity can arise from asset complementarity in systemic interdependencies, e.g. (hybrid) electric vehicles and charging infrastructure [13]. Thus, (private) investors may shy away from otherwise perfectly functioning technologies. The third category includes deep uncertainty that characterizes (radical) innovation. In such cases an NPV simply cannot be computed $[98,99]$. While financial intermediaries are specialists in managing risk through diversification and trading, noncalculable uncertainty cannot be managed using advanced risk management tools [100]. If it does not fit the risk model, the dominant players in modern financial markets are unwilling, but also simply unable to engage.
} 
has come to heavily depend on the smooth functioning of financial markets. Especially after the financial crises, a focus on risk reduction and stability is justified. But, paradoxically, minimizing financial risks at the micro level may expose the real economy to large climate risks.

Our contribution in this paper is that we synthesize the literature on clean-energy innovation and finance with a particular focus on innovation policy and financial market regulation, in order to understand why investment in the energy transition is lagging. We argue that innovation policy efforts alone would not be sufficient to jointly achieve financial system resilience and an innovationled transition toward a sustainable economy. The two are rarely discussed in coherence, so here we identify a gap in the literature, and make the case for diversity as an important element that can both stabilize financial systems and foster funding of investment required for the energy transition.

In the remainder of this paper we first discuss the most relevant trends in the financial system. Then we propose policies promoting more diversity in the financial sector that would address both the valid concern for financial stability and mobilize more resources to promote the energy transition.

\section{The financial system and the energy transition}

Deregulation, globalization and consolidation waves in the financial sector since the mid-1980s have, perhaps paradoxically, exacerbated a trend toward a homogenous financial system which culminated in the financial crisis of 2007 [19]. Haldane and May [20] and others [21 $\left.{ }^{\bullet}, 22\right]$ argue that part of the problem is the decline in diversity. It is not a problem per se that some intermediaries made mistakes and missed risks in their portfolio management strategies. A healthy ecosystem will simply flush out such faulty strategies through competition. The problem arises when all intermediaries start using the same strategies. Then risks, fully diversified at the micro level, become highly correlated across the system $\left[23,24^{\circ}\right]$. In addition, a more diverse and therefore more competitive financial environment could actually reduce the capital costs of clean energy, given that capital markets function more efficiently when markets are contested [25].

The crisis caused a regulatory backlash prioritizing size and secure assets (e.g. highly rated government or bluechip obligations) over diversity and more equity-like riskbearing assets (e.g. Venture Capital (VC) in innovative startups). Regulatory and supervisory entities reacted to the crisis by banning or severely restricting complex financial products. They formulated stricter resolution mechanisms to reduce implicit public guarantees, requiring high reserves for assets deemed more risky and curbing perverse incentives such as excessive bonuses [26-28]. Some of these tighter rules and regulations are particularly likely to adversely reduce the flow of funds and intermediation to new ventures $\left[29,30^{\bullet}, 31^{\circ}\right]$. It is clear that investment through equity and equity-like interest-bearing assets is most urgently needed and best suited for innovative firms (see Figure 1). Such assets are typically deemed risky, also by regulators that require high reserves be held by both banks and institutional investors. In addition, such investors need to price their assets 'to market' and as these assets are only rarely priced in deep, liquid markets, it is even often outright impossible to invest in such asset classes. Thus, a system dominated by regulated banks and institutional investors is likely to underfund the innovations a transition requires.

\section{Financing early-stage clean energy innovation}

In the early stages of the (clean energy) innovation cycle the challenges outlined above are partly overcome through R\&D grants and early-stage investors (Figure 1). However, their size is small in comparison, given their importance in driving a transformation to clean energy $\left[32,33^{\bullet}, 34,35\right]$. When it comes to early-stage finance, debt instruments are simply not available due to lack of collateral and track record [36]. Innovative firms often add market and technical uncertainty to the regulatory uncertainty. When investing in such ventures (also new business units by incumbent energy companies), intermediaries cannot rely on standard, modern risk-management techniques [37]. Instead they must establish trust in the investee through soft information and relationships or, alternatively, take a stake in the venture that also gives some control rights. This is what venture capitalists and business angels (and also friends and family) do $\left[38^{\bullet}, 39\right]$.

The problem with this model is that it cannot be easily scaled and involves large amounts of tacit knowledge in any single transaction. Moreover, the only countries in the world that can boast a significant $\mathrm{VC}$ and private equity (PE) market are the US, UK and Israel, where many complementary institutions support these sectors $\left[40,41,42^{\circ}\right]$. In particular Europe, with its highly concentrated and regulated, bank-dominated financial system, channels only a very small and declining fraction of its savings through these PE intermediation channels (to clean energy) [36]. While PE firms are entrusted with funds by institutional investors such as pension funds or, more precisely, their asset managers and banks, the vast bulk of Europe's substantial savings surplus is invested directly by institutional investors and banks themselves. These intermediaries are reluctant and, given their regulatory and fiduciary constraints and accounting practices, even outright prohibited to engage with deep uncertainty such as VC/PE investments.

Fintech solutions, such as crowdfunding and peer-to-peer lending, are growing, yet channel relatively small fractions of savings into early-stage investments $\left[33^{\bullet \bullet}, 43^{\circ}\right]$. 
Figure 1

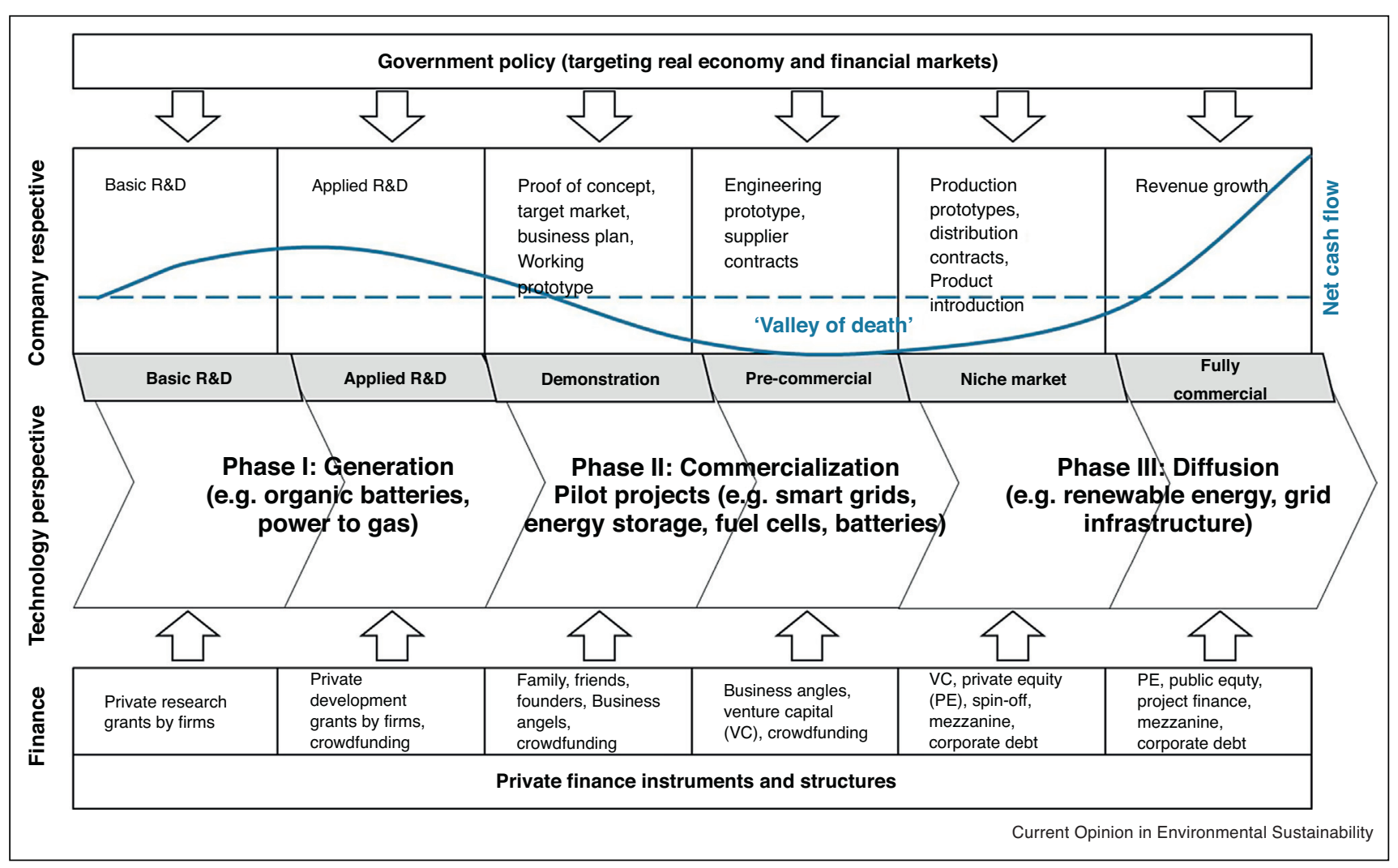

Financial instruments to finance clean energy innovation.

Adapted from $[58,75]$.

Such investments for example amount to only 358 USDm [35] compared to 1658 USDbn in corporate debt to nonfinancial firms in Europe [44]. These funding platforms bring back the judgment call aspect of relationship banking and VC, but 'scale' the investment process through organizing the flow of information in a different, nonproprietary way [45]. By making their decision known to the rest of the investor community, crowdfunders seem to be a promising source of finance for the energy transition by enabling community finance of smaller RE projects $\left[46^{\bullet}, 47^{\circ}\right]$.

\section{Financing later-stage clean energy diffusion and infrastructure}

The energy transition will inevitably feature significant investments in off-the-shelf technologies such as solar PV and wind that need to come from mature firms. In the later stage of the clean energy innovation cycle, additional sources of finance are available (see Figure 1) despite the fact that technology-specific problems such as long payback periods and policy uncertainty still prevail $\left[11^{\circ}\right]$. The remaining regulatory uncertainty implies the default risk on any project is substantial and, importantly, not calculable. This implies credit ratings are low or absent and only (private) equity or junk bonds can channel savings into these types of investments. This also affects established companies engaging in the energy transition.

In developed economies, later-stage corporate finance mostly comes from insurers, banks or pension funds [34]. They finance larger, mature clean energy companies as well as projects and infrastructure with debt or equity. Debt investors do not receive dividends and do not benefit from higher profitability and cost reductions directly. So they care about the downside much more than they do about the potential upsides. Hence incentives for debtors are to reduce capital expenditure (CAPEX) and leverage to have a better credit rating and thus lower cost of capital, increasing the value of the stock in the short run [48]. Asset managers of institutional investors also do not have strong incentives to push for operational expense (OPEX) reductions if such investments do not translate into (quick) capital gains, as they are typically evaluated and rewarded comparing performance to market benchmarks with high frequency. However, more patient capital, for example, from state investments banks, finances large-scale infrastructure projects (e.g. for e-mobility or hydrogen) that are needed 
to complement the decentralized energy transition [49]. In developing countries and emerging markets, on the other hand, financing of renewable energies takes on a very different stance. Given the lack of electrification in rural areas of regions such as India, Brazil or Sub-Saharan Africa, the decentralization of energy sources comes center-stage through off-grid energy supply. More importantly, this off-grid access to energy implies a very different, unscaleable business model that cannot rely on any conventional business-oriented financing source. Smallscale solar or wind projects are often funded through some co-operation between local project developers and public (development) banks, rather than multinational asset managers $[15,50,51]$ or crowdfunding $\left[52^{\circ}\right]$.

The focus of the ecosystem for financing toward debt and later stages creates a bias toward calculable risks in incremental innovation and, importantly, the maintenance and expansion of the existing capital stock in existing firms. These incumbents have high-quality marketable collateral and established track records, but lack the incentive to introduce and diffuse true innovations, as they cannibalize existing profit flows [53]. For example, oil companies like Shell and Exxon only hesitantly engage in clean energy.

\section{Policies to stimulate investments into clean energy}

Central governments arguably have the means to break the 'lock-in' problems which favor fossil-fuel-based energy technologies $\left[11^{\bullet \bullet}, 54,55\right]$. Mistakes, however, are terribly costly and can create new lock-ins for which politicians do not want to be held accountable. Sticking to the existing system may be more attractive, even at the country level, than running the chance of locking in to a losing technology. But there are some areas of policy where we do see some action.

\section{Innovation policy}

The obvious angle from which policy makers could approach the challenges for the energy transition is innovation policy $\left[11^{\bullet \bullet}, 12,55\right]$. Market-based incentives such as GHG emissions-trading systems represent the theoretical optimum as argued by climate and energy economics since the early 1990 s $\left[56,57^{\bullet \bullet}\right]$. However, due to the lack of global mechanisms, second-best instruments are required. To accelerate the diffusion of clean energy and associated investments, policy makers first could deploy technologypush mechanisms such as direct R\&D investments, subsidies and tax-credits that target the early stages of the innovation cycle or early stage $\mathrm{VC} / \mathrm{PE}$ which favors SMEs [32,36,58]. Direct investments and co-funding also mobilize private early-stage finance $[59,60]$. Olmos and colleagues [32] suggest public loans, or guarantees provided by public bodies backing private loans, along with public investments in the equity of innovating companies to accelerate the commercialization. By getting more involved in financing investments directly, the government would increase financial diversity, as the criteria and conditions under which such public funds become available will differ from those offered by banks and institutional investors today $\left[55,61^{\circ}\right]$.

Second, research conducted on clean energy diffusion and investment highlighted demand-pull policies mostly targeting the later stages of the innovation cycle $[58,62,63]$. Fiscal and financial incentives such as grants and subsidies $[32,36,64]$ prove less effective than feed-in tariffs $\left[65-68,69^{\bullet \bullet}\right]$ that also target smaller distributed capacity and early stage investments that again benefits smaller players $\left[47^{\bullet}, 70^{\bullet \bullet}\right]$. To address network externalities and reduce private risks regarding complementary assets (e.g. infrastructure), public investments have been suggested [71,72]. The (quality) regulation of the (clean energy) portfolio and emission standards advances deployment of more mature technologies [73,74]. Systemic policies such as standard-setting, long-term planning and policy support accelerate both early and later investments $\left[36,61^{\bullet}, 75,76\right]$. In particular, consistency, stringency and predictability to reduce deep uncertainty and policy risk are deemed crucial [77,78]. Overall, a policy mix is suggested to make the transition [79 $\left.{ }^{\circ}\right]$. Most of these policies, however, actually favor mature, established technologies geared toward the existing monoculture of debtbased financial markets.

\section{Framework conditions and financial market regulation}

Unprecedented monetary policies in the Eurozone (Quantitative Easing) have driven the cost of debt finance to zero or below and flooded financial markets with cheap debt finance. Still only very little of that monetary expansion finds its way into the real economy, let alone into clean energy $\left[34,80^{\bullet \bullet}\right]$. Instead, we argue that these policies tend to entrench the existing linear, carbon-based economy, as debt favors the low-risk status quo. More equity and, more specifically, PE investments are needed to finance uncertain but much-needed innovation (both for incumbent firms and new ventures). Hence, the less obvious but equally important angle from which policy makers affect private investment for clean energy consists of framework conditions and financial market regulation.

Framework conditions for either debt or equity-based instruments influence their contribution to a clean energy transition, as a developed capital market is needed to channel resources $\left[42^{\bullet}, 81\right]$. Most importantly, a fiscal preferential treatment of debt finance, which is widespread today, should be avoided. Typically, interest is deductable as costs, while dividend payments only occur after tax. Policy makers should try to level the playing field across sources of finance. Hence a favorable tax policy could allow for tax deductibility of early-stage company investments [82,83]. A less stringent bankruptcy and labor market legislation would also promote entrepreneurship and 
experimentation in sectors characterized by high uncertainty, such as cleantech [84]. Securities legislation should allow VC funds to sell parts of their investments [84].

Capital market regulation shapes investment mandates and risk models and thus ultimately determines the feasibility and viability of investments into clean energy $\left[80^{\bullet \bullet}, 85\right]$. Regulation (e.g. Basel III, Solvency II), especially since the crisis, is almost exclusively geared toward stability and security [26,28,83]. Consequently, they encourage or force deposits into 'safe' asset classes and calculable risks, such as rated (energy) firms, government debt and real estate. Institutional investors and their intermediaries are forced to stay away from risky asset classes such as $\mathrm{VC} / \mathrm{PE}\left[29,80^{\bullet \bullet}, 86\right]$. A solution would be to 'loosen' equity requirements for green investments specifically $\left[80^{\circ}\right]$. But this would put the deposits and pension premium at risk. More fundamentally, one should therefore look for ways to clearly separate intermediation and investment from transactions and savings, as not all deposits are held for investment purposes [87]. A no-regret is to require financial intermediaries to lower their overall leverage ratio and operate with more equity [88]. With more skin in the game, banks and institutional investors can responsibly handle more risk and uncertainty on their balance sheets. The current practice of discriminating among asset classes (e.g. Basel III) on measurable risk seems to make perfect sense, until one realizes this inevitably works against innovative entrepreneurs, who face deep uncertainty and have no track record and collateral to secure their loans.

Alternative intermediaries such as $\mathrm{VC} / \mathrm{PE}$ have also become regulated, for example through the Alternative Investment Fund Managers (AIFM) Directive, increasing reporting burdens and forcing funds to accumulate more capital to cover higher costs, hence reducing diversity in the system. Prospects for more VC/PE - or even more traditional friends, family and fools financing - is limited in the more egalitarian European welfare states as there are fewer wealthy private investors than in the US and UK who can freely invest their wealth [83]. Fiscal reforms in the tax treatment of private wealth, gifts and bequests and arms-length investments could go a long way to direct more (equity) investments to ventures and projects that would otherwise stay unfunded [89].

New alternative finance such as equity and debt-based crowdfunding could also benefit greatly from such reforms $\left[90^{\circ}\right]$, but instead are also becoming more regulated in many countries [91]. Regulators should abstain from clamping down on shadow banking and new forms of intermediation, for example through a regulatory sandbox [92]. This will prove harder than one might think, as the 'experts' in traditional banking and even PE and VC will warn for 'irresponsible risks' being taken there [93]. Moreover, ordinary people will lose money, inevitably creating political pressure for such regulatory tightening. It is more promising to be clear about the fact that such investments are not regulated and that investors willingly accept uncertainty and risk. As we have argued above, however, the volumes to be expected from these emerging intermediation channels are limited.

While many clean energy investments projects are economical, the question is why even these are not funded under record-low interest rates. This problem stems from unintended consequences of stability-oriented regulation that constrain existing intermediaries to channel funds to risky ventures and even long-term RE projects. In addition, this lack of transmission to the real economy stifles the effectiveness of monetary easing $\left[80^{\bullet \bullet}\right]$. To alleviate this problem of diffusion, together with issues of innovation financing, a more co-ordinated approach of policy measures is warranted. Such policies will result in a more diverse and therefore more stable financial system that at the same time channels more resources into the risky, but urgent, transition to a more sustainable real economy.

\section{Conclusion}

In this paper we show that in the discussion about mobilizing private finance for clean energy innovation, the literature has neglected the structure and regulation of financial markets as potential determinants. In order to mobilize resources to break out of the fossil fuel technology complex and to finance radical and transformative innovations, we need intermediation to take different channels (see Figure 1). More risk at the micro level in a more diverse financial system implies we stand a chance of avoiding macro catastrophe. While low-risk institutionalized debt finance is at best suitable to finance diffusion (but more likely channels our resources into the riskless reproduction of the status quo), a shift to more expensive and uncertain equity is needed to finance innovation. Financial market regulations are currently 'boxing in' intermediaries in a way that biases finance toward the status quo and it is not responding to the financial requirements of an innovation-led energy transition (e. g. early-stage risk capital, equity, risk-bearing debt, etc.).

Financial regulatory reforms could free up the resources in banks and institutional investors for more uncertain and equity-like intermediation. This may imply a shortening of bank and pension fund balance sheets and more risk landing with individual small-scale investors. But this risk will be rewarded in higher returns. The ensuing diversity in intermediation will increase financial resilience and shift the bias in intermediation (back to) the innovative experimentation we desperately need. Regulators, however, can also allow banks and intermediaries to take higher risks with their assets, if they compensate such higher risk with higher equity ratios. In the end, implicit and explicit guarantees for deposits and other debt liabilities on the banks' balance sheets must be 
eliminated altogether. This sets the necessary preconditions for a more diverse financial sector in which all varieties of intermediation compete on a level playing field, and implicit public support for banks no longer tilts the system toward cheap debt finance of status quo assets. A more diverse financial system allows for an (easier) transition toward clean energy.

\section{Conflict of interest}

None declared.

\section{References and recommended reading}

Papers of particular interest, published within the period of review, have been highlighted as:

- of special interest

•• of outstanding interest

1. Jefferson M: Accelerating the transition to sustainable energy systems. Energy Policy 2008, 36:4116-4125.

2. Hall S, Foxon TJ, Bolton R: Investing in low-carbon transitions: -. energy finance as an adaptive market. Clim Policy 2015:1-19.

This highly policy relevant article explores theories behind the neoclassical approach to innovation finance taking which assume that capital markets function efficiently and the structural co-evolutionary approach that emphasizes social mechanism to influence financiers behavior. On the basis of the analysis of the UK electricity market reform and renewable energy finance the authors propose a theoretical lens that takes into account planetary boundaries. The adaptive market hypothesis states that the investment environment together with investors' behavior can change over time implicating that behavioral and structural conditions work in financial markets.

3. Rosen RA, Guenther E: The economics of mitigating climate change: what can we know? Technol Forecast Soc Change 2014 http://dx.doi.org/10.1016/j.techfore.2014.01.013.

4. IPCC: Climate Change 2014: Mitigation of Climate Change IPCC Working Group III Contribution to AR5. Int.. 2014.

5. Iyer G, Hultman N, Eom J, McJeon H, Patel P, Clarke L: Diffusion

- of low-carbon technologies and the feasibility of long-term climate targets. Technol Forecast Soc Change 2015, 90:103-118. In this paper, the authors model the necessary large-scale deployment of low-carbon technologies. Next to economic factors hindering the adoption, the analysis points to institutional, behavioral and social factors that relate to both the uncertainty in climate policy as well as technology inherent characteristics. Technological lock-in, network externalities, high upfront investments, uncertainty and policy risk are highlighted. Even without major delays in policy implementation, the diffusion of low-carbon technologies might be hindered, especially if the technologies are interdependent. For some technologies such as CCS and renewables the constraints are more costly than for others (e.g. nuclear and bioenergy).

6. Stern N: Economic development, climate and values: making policy [Internet]. Proc R Soc B 2015, 282.

7. van den Bergh J, Folke C, Polasky S, Scheffer M, Steffen W: What

- if solar energy becomes really cheap? A thought experiment on environmental problem shifting. Curr Opin Environ Sustain $2015,14: 170-179$

The authors outline the environmental problem-shifting phenomenon which occurs when technologies aimed at solving certain problems have reverse salients and negative side effects. Using a qualitative scenario approach the authors show potential rebound effects, using the example of mass-diffusion of solar energy which is an important scenario for the coming years. In a world where fossil fuels are expensive due to a carbonemission scheme the environmental impact of cheap solar technologies are modest as energy efficiency measures make the overall economy smaller. In unconstraint scenarios cheap solar energy could mean less $\mathrm{CO}_{2}$ reduction but on the other hand more ocean acidification and increased land-use and loss of biodiversity.

8. IEA: Energy and Climate Change - World Energy Outlook Special Report. International Energy Agency; 2015.
9. IEA: World Energy Outlook 2015 [Internet]. International Energy Agency; 2015.

10. IEA: World Energy Investment Outlook [Internet]. International Energy Agency; 2016.

11. Polzin F: Mobilizing private finance for low-carbon

-. innovation - a systematic review of barriers and solutions. Renew Sustain Energy Rev 2017, 77:525-535.

This article is one of the first to systematically integrate the consequences of barriers to low-carbon innovation for innovation financing along the innovation cycle. Drawing from the innovation studies and entrepreneurial/innovation finance literatures the author emphasizes that technologi$\mathrm{cal}$, economic, institutional and political barriers have the most pronounced effect on investment. Policy makers possess a variety of instruments to address the barriers ranging from cutting fossil fuel (R\&D) subsidies, leveling the institutional playing field and making risks of high-carbon and low-carbon technologies transparent to providing a consistent but adaptive long-term transition strategy.

12. van den Bergh JCJM: Environmental and climate innovation: limitations, policies and prices. Technol Forecast Soc Change 2013, 80:11-23.

13. Negro SO, Alkemade F, Hekkert MP: Why does renewable energy diffuse so slowly? A review of innovation system problems. Renew Sustain Energy Rev 2012, 16:3836-3846.

14. Perez C: Technological Revolutions and Financial Capital: The Dynamics of Bubbles and Golden Ages. Edward Elgar Publishing; 2002.

15. Friebe $\mathrm{CA}$, von Flotow $\mathrm{P}$, Täube FA: Exploring technology diffusion in emerging markets - the role of public policy for wind energy. Energy Policy 2014, 70:217-226.

16. Mathews JA, Kidney S, Mallon K, Hughes M: Mobilizing private finance to drive an energy industrial revolution. Energy Policy 2010, 38:3263-3265.

17. Mazzucato M: Financing innovation: creative destruction vs. destructive creation. Ind Corp Change 2013, 22:851-867.

18. Demirel P, Parris S: Access to finance for innovators in the UK'S - environmental sector. Technol Anal Strateg Manag 2015, 27:782808 .

The authors show the early-stage finance gap specifically for innovative SMEs in the environmental sector using data from 330 firms. In this seminal study in the green tech sector, they argue that banks but also government support schemes discriminate SMEs that develop nascent technologies and venture capitalists fill this gap only to a very limited extend. Retained profits are hence the only way to finance these activities.

19. Mazzucato M: The Entrepreneurial State: Debunking Public vs. Private Sector Myths. Anthem Press; 2013.

20. Haldane AG, May RM: Systemic risk in banking ecosystems. Nature 2011, 469:351-355.

21. Fricke D: Has the banking system become more

- homogeneous? Evidence from banks' loan portfolios. Econ Lett 2016, 142:45-48.

In this paper, the similarity of loan portfolio in the Japanese banking system over the last 20 years is examined. The author finds that although overall similarity has decreased the banking system has become more concentrated and the largest banks have indeed become more similar. He concludes that the findings are likely to hold for other bank-based financial system such as Germany or the Netherlands.

22. Beunza D, Stark D: From dissonance to resonance: cognitive interdependence in quantitative finance. Econ Soc 2012, 41:383-417.

23. Battiston S, Caldarelli G, Georg C-P, May R, Stiglitz J: Complex derivatives. Nat Phys 2013, 9:123-125.

24. Cueva C, Rustichini A: Is financial instability male-driven?

- Gender and cognitive skills in experimental asset markets. J Econ Behav Organ 2015, 119:330-344.

This article looks at the origins of financial instability that led to the past financial crises and impact financing the real economy. On the basis of experimental evidence in constructed asset markets, the authors highlight that male and female markets have comparable volatility, however confidence and risk preference (male attributes) drive financial instability. Hence reducing male domination and creating mixed-gender markets 
contribute to stability. Overall higher cognitive skills are associated with reduced price volatility.

25. Szabó S, Jäger-Waldau A: More competition: threat or chance for financing renewable electricity? Energy Policy 2008, 36:1436-1447.

26. European Commission: Survey on the Access to Finance of Enterprises (SAFE) - Analytical Report 2014 [Internet]. European Commission; 2014.

27. 111th Congress of the United States of America: Dodd-Frank Wall Street Reform and Consumer Protection Act [Internet]. 2010.

28. Bank for International Settlements: International Regulatory Framework for Banks (Basel III) [Internet]. 2010.

29. Block J, Sandner P: What is the effect of the financial crisis on venture capital financing? Empirical evidence from US Internet start-ups. Venture Cap. Int J Entrep Finance 2009, 11:295-309.

30. Cowling M, Liu W, Minniti M, Zhang N: UK credit and - discouragement during the GFC. Small Bus Econ 2016, 47:10491074.

The authors of this seminal paper show that during the financial crises, a small (2.5\%) but significant number of UK SMEs have been discouraged through the perception of the market environment to apply for a loan. These firms also appear more risky but are aware of their riskiness. The financial crises added noise and uncertainty to the lending process to SMEs. Entrepreneurs also overrated the extend to which credit rationing was ongoing, which lead to sub-optimal lending activities.

31. Migendt M, Polzin F, Schock F, Täube FA, von Flotow P:

- Beyond venture capital: an exploratory study of the finance-innovation-policy nexus in cleantech [Internet]. Ind Corp Change $2017 \mathrm{http} / / / \mathrm{dx}$. doi.org/10.1093/icc/dtx014.

This article builds theory around unintended consequences of financial market regulation after the financial crisis for the financing of innovative cleantech companies. On the basis of 64 semi-structured interviews in the US and Germany the authors shed light on mechanisms of demand and supply for venture capital (VC) and private equity (PE) along the innovation-finance-value chain. Institutional investors emerge as critical players, particularly negatively affected by financial market regulation that restricts their possibilities to investment in risky asset classes such as VC/ $\mathrm{PE}$.

32. Olmos L, Ruester S, Liong S-J: On the selection of financing instruments to push the development of new technologies: application to clean energy technologies. Energy Policy 2012, 43:252-266.

33. Block JH, Colombo MG, Cumming DJ, Vismara S: New players in

-. entrepreneurial finance and why they are there. Small Bus Econ $2017 \mathrm{http}: / / \mathrm{dx}$.doi.org/10.1007/s11187-016-9826-6.

The authors provide a state-of-the-art overview about new actors in financial markets, the antecedents of their emergence and their peculiarities with regard to financing entrepreneurship and innovation. The authors compare nature of the capital (debt or equity), investment approach, goal and targets. They highlight the emergence of disintermediated players such as crowdfunding in addition to 'classical' entrepreneurial financiers such as VC and business angels. However the literature is biased towards these, neglecting other players such as family offices.

34. McCrone A, Moslener U, d'Estais F, Usher E, Grüning C: Global Trends in Renewable Energy Investment 2016 [Internet]. 2016.

35. Zhang B, Wardrop R, Ziegler T, Lui A, Burton J, James A, Garvey K: Moving Mainstream The European Alternative Finance Benchmarking Report. University of Cambridge; 2016.

36. Bergek A, Mignon I, Sundberg G: Who invests in renewable electricity production? Empirical evidence and suggestions for further research. Energy Policy 2013, 56:568-581.

37. Bhidé A: A Call for Judgment: Sensible Finance for a Dynamic Economy. USA: Oxford University Press; 2010.

38. Bocken NMP: Sustainable venture capital - catalyst for - $\quad$ sustainable start-up success? J Clean Prod 2015, 108:647-658. This paper represents an important addition to the discussion about the suitability of venture capital for sustainable start-ups. On the basis of a series of interviews with investors and other stakeholders the author extracts drivers and barriers for successful venture capital engagement in sustainable firms. Key success factors include an innovative business model, collaborations with other stakeholders and a strong business case, whereas failure factors include a mismatch between investors and entrepreneur, a strong incumbent industry and a short-term investor mind-set of potential investor. The study underlines the important role of venture capitalists play in advancing the sustainability transition.

39. Kotha R, George G: Friends, family, or fools: entrepreneur experience and its implications for equity distribution and resource mobilization. J Bus Ventur 2012, 27:525-543.

40. Hirsch-Kreinsen H: Financial market and technological innovation. Ind Innov 2011, 18:351-368.

41. Bertoni F, Colombo MG, Quas A: The patterns of venture capital investment in Europe. Small Bus Econ 2015, 45:543-560.

42. Cumming D, Henriques I, Sadorsky P: 'Cleantech' venture - capital around the world. Int Rev Financ Anal 2016, 44:86-97. This research article provides the first cross-country account of drivers and barriers to venture capital investing in the cleantech sector from 1996 to 2010. Key drivers for this phenomenon include in descending order of importance: Media attention, rising oil prices and formal (e.g. regulatory quality and government effectiveness) and informal institutions. Uncertainty avoidance on the other hand represents a significant barrier, hence this need to be addressed in order to mobilize more private finance for cleantech.

43. Bruton G, Khavul S, Siegel D, Wright M: New financial

- alternatives in seeding entrepreneurship: microfinance, crowdfunding, and peer-to-peer innovations. Entrep Theory Pract 2015, 39:9-26.

This paper starts the discussion about new forms of entrepreneurial finance that increase diversity in the financing landscape for start-ups. They establish an analytical framework for these new alternatives consisting of sources and types of capital, demand for capital (entrepreneurs perspective), resulting ownership and governance structures of the ventures as well as outcomes of the investment process.

44. Bank for International Settlements: C1 Summary of Debt Securities Outstanding [Internet]. Debt Secur Stat; 2017.

45. Polzin F, Toxopeus $\mathrm{H}$, Stam $\mathrm{E}$ : The wisdom of the crowd in funding: information heterogeneity and social networks of crowdfunders. Small Bus Econ 2017 http://dx.doi.org/10.1007/ s11187-016-9829-3.

46. Etzion D, Gehman J, Ferraro F, Avidan M: Unleashing

- sustainability transformations through robust action. $J$ Clean Prod 2017, 140(Pt 1):167-178.

This recent piece contributes to the discussion of how to accelerate the transition towards a green economy. On the basis of the case-study analysis of wind power, sustainability reporting and microcredit, the authors argue that instead of long-term visioning, planning and other management tools, robust action is appropriate to solving grand challenges such as climate change. Robust action consists of 'leaders' (organizations or individuals) that despite limited formal authority are able to leverage networks and actors to spur decentralized innovation.

47. Vasileiadou E, Huijben JCCM, Raven RPJM: Three is a crowd? - Exploring the potential of crowdfunding for renewable energy in the Netherlands. J Clean Prod 2016, 128:142-155.

Crowdfunding might fill the gap needed for an energy transition. The authors of this paper analyze a potential contribution based on a case study of wind energy in the Netherlands. Because of the low volumes (often too low for renewable energy projects), small scale, limited institutional support (e.g. from financial market authorities) and from incumbent regime actors such as electricity companies, the potential for crowdfunding to drive the energy transition is limited.

48. Haldane AG: The costs of short-termism. Rethinking Capitalism: Economics and Policy for Sustainable and Inclusive Growth. Wiley Blackwell; 2016.

49. Mazzucato M, Penna CCR: Beyond market failures: the market creating and shaping roles of state investment banks. J Econ Policy Reform 2016, 19:305-326.

50. Friebe CA, Flotow $P$ von, Täube FA: Exploring the link between products and services in low-income markets - evidence from solar home systems. Energy Policy 2013, 52:760-769.

51. Urpelainen J, Yoon S: Solar home systems for rural India: survey evidence on awareness and willingness to pay from Uttar Pradesh. Energy Sustain Dev 2015, 24:70-78.

52. Cumming DJ, Leboeuf G, Schwienbacher A: Crowdfunding

- cleantech. Energy Econ 2017, 65:292-303. 
This paper presents a first analysis of cleantech crowdfunding, thereby providing insights on the financing of new alternative energy technologies by enabling inferences from large pools of small investors. It provides large sample evidence from 91 countries around the world that cleantech crowdfunding is more common when oil prices are rising, and more common in countries with low levels of individualism and uncertainty avoidance. The evidence is consistent with the view that while alternative energies are viewed as being more risky and investors face greater information asymmetries relative to other types of investment projects, there are mechanisms for entrepreneurs to mitigate these information problems and be at least as successful in cleantech crowdfunding markets.

53. Hockerts K, Wüstenhagen R: Greening Goliaths versus emerging Davids - theorizing about the role of incumbents and new entrants in sustainable entrepreneurship. J Bus Ventur 2010, 25:481-492.

54. Smink MM, Hekkert MP, Negro SO: Keeping sustainable innovation on a leash? Exploring incumbents' institutional strategies. Bus Strateg Environ 2015, 24:86-101.

55. Mazzucato M, Semieniuk G: Public financing of innovation: new questions. Oxf Rev Econ Policy 2017, 33:24-48.

56. Fischer C, Newell RG: Environmental and technology policies for climate mitigation. J Environ Econ Manag 2008, 55:142-162.

57. Polzin F, Migendt M, Täube FA, von Flotow P: Public policy - influence on renewable energy investments - a panel data study across OECD countries. Energy Policy 2015, 80:98-111. In this account, the authors consolidate the literature on policy measures for renewable energy deployment and investment. It investigates the direct effect of policy instruments on investments in renewable energy technologies across a set of OECD countries in a longitudinal panel analysis. Results show that economic and fiscal incentives such as feed-in tariffs, mobilize institutional investors especially for less mature technologies whereas market-based instruments such as greenhouse gas emission trading systems are conducive to investments in mature technologies.

58. Bürer MJ, Wüstenhagen R: Which renewable energy policy is a venture capitalist's best friend? Empirical evidence from a survey of international cleantech investors. Energy Policy 2009, 37:4997-5006

59. Bird LA, Bolinger M, Gagliano T, Wiser R, Brown M, Parsons B: Policies and market factors driving wind power development in the United States. Energy Policy 2005, 33:1397-1407.

60. Menz FC, Vachon S: The effectiveness of different policy regimes for promoting wind power: experiences from the states. Energy Policy 2006, 34:1786-1796.

61. Manning S, Reinecke J: A modular governance architecture

- in-the-making: how transnational standard-setters govern sustainability transitions. Res Policy 2016, 45:618-633.

The authors provide an important perspective on sustainability transitions. They examine how the multi-level processes can be effectively governed taking transnational standard setters and the global coffee industry as an example. Relevant modules for a global governance (e.g. banning environmental harmful pesticides or ensure fair incomes for farmers) emerge in niche-markets and these standard setters ensure compatibility and diffusion across other countries.

62. Haley UCV, Schuler DA: Government policy and firm strategy in the solar photovoltaic industry. Calif Manag Rev 2011, 54:17-38.

63. Hoppmann J, Peters M, Schneider M, Hoffmann VH: The two faces of market support - how deployment policies affect technological exploration and exploitation in the solar photovoltaic industry. Res Policy 2013, 42:989-1003.

64. Roy J, Ghosh D, Ghosh A, Dasgupta S: Fiscal instruments: crucial role in financing low carbon transition in energy systems. Curr Opin Environ Sustain 2013, 5:261-269.

65. Couture T, Gagnon Y: An analysis of feed-in tariff remuneration models: implications for renewable energy investment. Energy Policy 2010, 38:955-965.

66. del Río P, Bleda M: Comparing the innovation effects of support schemes for renewable electricity technologies: a function of innovation approach. Energy Policy 2012, 50:272-282.
67. Jenner S, Groba F, Indvik J: Assessing the strength and effectiveness of renewable electricity feed-in tariffs in European Union countries. Energy Policy 2013, 52:385-401.

68. Marques AC, Fuinhas JA: Are public policies towards renewables successful? Evidence from European countries. Renew Energy 2012, 44:109-118.

69. Rodríguez MC, Hačič I, Johnstone N, Silva J, Ferey A: Renewable -. energy policies and private sector investment: evidence from financial microdata. Environ Resour Econ 2015, 62:163-188.

Building on unique investment micro-data (deal level) from Bloomberg New Energy Finance, this paper analyses the effect of a set of public policy instruments on investments in renewable energy in 87 countries from 2000 to 2011. Price-based instruments such as feed-in tariffs are positively related to private financial contributions. However when public entities co-finance a project no policy instrument mobilizes private finance.

70. Criscuolo C, Menon C: Environmental policies and risk finance

-. in the green sector: cross-country evidence. Energy Policy 2015, 83:38-56

The study provides an important link between the policies supporting green technologies and early-stage venture capital investments looking at 29 countries over a five-year period (2005-2010). The authors show both supply-push policies such as R\&D support as well as demand-pull measures such as long-term feed-in tariff programs correspond to the demand for long-term stable policy support systems to mobilize private early-stage investments for green tech. A policy mix including these two elements is thus advisable according to the researchers.

71. Henriot A: Financing investment in the European electricity transmission network: consequences on long-term sustainability of the TSOs financial structure. Energy Policy 2013, 62:821-829.

72. Steinbach A: Barriers and solutions for expansion of electricity grids - the German experience. Energy Policy 2013, 63:224229.

73. Delmas MA, Montes-Sancho MJ: U.S. state policies for renewable energy: context and effectiveness. Energy Policy 2011, 39:2273-2288.

74. Carley S: State renewable energy electricity policies: an empirical evaluation of effectiveness. Energy Policy 2009, 37:3071-3081

75. Wüstenhagen R, Menichetti E: Strategic choices for renewable energy investment: conceptual framework and opportunities for further research. Energy Policy 2012, 40:1-10.

76. Masini $A$, Menichetti $E$ : The impact of behavioural factors in the renewable energy investment decision making process: conceptual framework and empirical findings. Energy Policy 2012, 40:28-38.

77. White W, Lunnan A, Nybakk E, Kulisic B: The role of governments in renewable energy: the importance of policy consistency. Biomass Bioenergy 2013, 57:97-105.

78. Lüthi $\mathrm{S}$, Wüstenhagen R: The price of policy risk - empirical insights from choice experiments with European photovoltaic project developers. Energy Econ 2012, 34:1001-1011.

79. Rogge KS, Reichardt K: Policy mixes for sustainability

- transitions: an extended concept and framework for analysis. Res Policy 2016, 45:1620-1635.

Effective and efficient policy mixes are an important element of an innovation-led sustainability transition. Interacting instruments and policy strategy are elements of this analytical framework that can be applied to whole innovation systems, sectors or specific technologies. It allows policy maker to assess their impact on technological change in critical sectors such as energy. Consistency in policy instruments and coherence in policy processes are specifically valued by financial market actors.

80. Campiglio E: Beyond carbon pricing: the role of banking and -. monetary policy in financing the transition to a low-carbon economy. Ecol Econ 2016, 121:220-230.

This unique paper examines the possible role of banks, banking regulation and monetary policy in a transition towards a sustainable economy. The author argues that in addition to fixing market and system failures surrounding low-carbon innovation, more direct instruments to mobilize private finance such as expanding credit creation towards green 
technologies through green reserve requirements as well as state investments banks are needed to fill the investment gap.

81. Da Rin M, Nicodano G, Sembenelli A: Public policy and the creation of active venture capital markets. J Public Econ 2006 90:1699-1723.

82. Keuschnigg C, Nielsen SB: Tax policy, venture capital, and entrepreneurship. J Public Econ 2003, 87:175-203.

83. Lerner J, Tåg J: Institutions and venture capital. Ind Corp Change 2013, 22:153-182.

84. Cumming D: Public policy and the creation of active venture capital markets. Ventur Cap 2011, 13:75-94.

85. Schmidt TS: Low-carbon investment risks and de-risking. Nat Clim Change 2014, 4:237-239.

86. Marcus A, Malen J, Ellis S: The promise and pitfalls of venture capital as an asset class for clean energy investment research questions for organization and natural environment scholars. Organ Environ 2013, 26:31-60.

87. Boot AWA, Thakor AV: Can relationship banking survive competition? J Finance 2000, 55:679-713.

88. Cohen $\mathrm{BH}$, Scatigna $\mathrm{M}$ : Banks and capital requirements: channels of adjustment. J Bank Finance 2016, 69(Suppl 1):S56S69.

89. Elert N, Henrekson M, Stenkula M: Institutional Reform for Innovation and Entrepreneurship. Springer Publishers; 2017.

90. Hornuf L, Schwienbacher A: Should securities regulation

- $\quad$ promote equity crowdfunding? Small Bus Econ $2017 \mathrm{http}: / / \mathrm{dx}$ doi.org/10.1007/s11187-017-9839-9.

This paper shows that too strong investor protection may harm smal firms and entrepreneurial initiatives, which contrasts with the traditiona 'law and finance' view that stronger investor protection is better. This situation is particularly relevant in equity crowdfunding, which refers to a recent financial innovation originating on the Internet that targets small and innovative firms. The paper shows that optimal regulation depends on the availability of an alternative early-stage financing such as venture capital and angel finance.

91. Vismara S: Equity retention and social network theory in equity crowdfunding. Small Bus Econ 2016, 46:579-590.

92. Authority FC: Regulatory Sandbox [Internet]. 2015.

93. Estrin S, Gozman D, Khavul S: Case Study of the Equity Crowdfunding Landscape in London: An Entrepreneurial and Regulatory Perspective. 2016.

94. Enkvist $P$, Nauclér T, Rosander J: A cost curve for greenhouse gas reduction. McKinsey Q 2007, 1:34.

95. Porter ME, van der Linde C: Toward a new conception of the environment-competitiveness relationship. J Econ Perspect 1995, 9:97-118.

96. Ambec S, Cohen MA, Elgie S, Lanoie P: The Porter hypothesis at 20: can environmental regulation enhance innovation and competitiveness? Rev Environ Econ Policy 2013, 7:2-22.

97. Jaffe $A B$, Newell RG, Stavins RN: A tale of two market failures: technology and environmental policy. Ecol Econ 2005, 54:164174.

98. Kenney M, Hargadon A: Misguided policy? Calif Manag Rev 2012, 54:118-139.

99. Knight FH: Risk, Uncertainty and Profit. Houghton Mifflin Corporation; 1921.

100. Bhidé A: How novelty aversion affects financing options. Capital Soc 2006, 1:1-2. 